Check for updates

Cite this: RSC Adv., 2019, 9, 9709

Received 26th January 2019

Accepted 20th March 2019

DOI: 10.1039/c9ra00702d

rsc.li/rsc-advances

\section{Discovery of methylpyrimidine ring-fused diterpenoid analogs as a novel testosterone synthesis promoter $\dagger$}

\author{
Jie Bai, $\neq^{a}$ Jia Xie, $\dot{t}^{\mathrm{b}}$ Li-Ting Wang, ${ }^{\mathrm{a}}$ Yajing Xing, ${ }^{\mathrm{b}}$ Qian-Ru Jiang, ${ }^{\mathrm{a}}$ Fan Yang, (D) ${ }^{a}$ \\ Jie Tang, ${ }^{a}$ Zhengfang $\mathrm{Yi}^{* \mathrm{~b}}$ and Wen-Wei Qiu (D) *a
}

Herein we screened our small synthetic library of diterpenoid analogs for hit compounds on promoting testosterone synthesis and the methylpyrimidine ring-fused diterpenoid analog 7 was obtained as the hit. Based on the hit, a series of derivatives were designed, synthesized and evaluated for their effects on testosterone secretion in mouse Leydig TM3 cells. Most of the derivatives showed better activity in promoting testosterone synthesis than the positive control compound icariin, among which compound 17 has optimal activity and little cytotoxicity. Preliminary mechanism studies indicated that 17 significantly promoted the expression of testosterone synthesis-related marker genes (StAR, 3 $\beta-H S D$ and CYP11A1). Further studies showed that 17 provided sufficient steroid materials for testosterone synthesis by stimulating autophagy in Leydig cells. Thus compound 17 emerged as a potential lead compound for further development of therapeutics for late onset of hypogonadism $(\mathrm{LOH})$.

\section{Introduction}

Diterpenoids are a major branch of natural products which exert many different biological activities. ${ }^{1}$ For instance, antiproliferative, ${ }^{2}$ multi-drug resistance-reversing, ${ }^{3}$ antimicrobial, ${ }^{4}$ vasoactive, ${ }^{5}$ antidiabetic, ${ }^{6}$ anti-osteoporosis ${ }^{7}$ immunomodulatory, ${ }^{8}$ and anti-inflammatory ${ }^{9}$ effects. Therefore, diterpenoids play an important role in the discovery of novel bioactive agents.

Testosterone, which is primarily produced in Leydig cells as the major circulating androgen, plays important roles in sexual differentiation, secondary sex characteristics, reproductive function and sexual function. ${ }^{\mathbf{1 0 , 1 1}}$ Serum testosterone deficiency causes late onset of hypogonadism $(\mathrm{LOH})$, which is a clinical and biochemical syndrome. ${ }^{12}$ The incidence rates of $\mathrm{LOH}$ are $13 \%, 30 \%$ and $47 \%$ for men aged $40-49,50-59$ and over 70 respectively. ${ }^{13}$ Previous studies indicated that LOH-related hypogonadal symptoms included sexual desire decrease, muscle mass and strength reduction, osteoporosis, increased

\footnotetext{
${ }^{a}$ Shanghai Engineering Research Center of Molecular Therapeutics and New Drug Development, School of Chemistry and Molecular Engineering, East China Normal University, 3663 North Zhongshan Road, Shanghai 200062, China. E-mail: wwqiu@ chem.ecnu.edu.cn; Tel: +86-21-54340103

${ }^{b}$ Shanghai Key Laboratory of Regulatory Biology, Institute of Biomedical Sciences, School of Life Sciences, East China Normal University, Shanghai 200241, China. E-mail: zfyi@bio.ecnu.edu.cn; Tel: +86-21-54345016

$\dagger$ Electronic supplementary information (ESI) available: Spectrum of the corresponding compounds. ${ }^{1} \mathrm{H}$ and ${ }^{13} \mathrm{C}$ NMR spectra of all final compounds. See DOI: $10.1039 / \mathrm{c} 9 \mathrm{ra00702d}$

\$ These authors contributed equally.
}

central body fat, forgetfulness, loss of memory, difficulty in concentration, insomnia and erectile dysfunction (ED)..$^{14,15}$

Testosterone replacement therapy (TRT), as the main clinical treatment method for $\mathrm{LOH}$ at present, provides a wide range of benefits for hypogonadism, improving libido and sexual function, fertility, bone density, muscle mass, and quality of life. ${ }^{16,17}$ However the clinical efficacy and long-term safety of TRT remains controversial. TRT involves the direct administration of an exogenous hormone, and with this treatment, the androgen level in the serum is superphysiological and unstable. ${ }^{13}$ So, it has considerable side effects, for instance, testicular atrophy, erythropoiesis, prostate cancer, cardiovascular events, intrahepatic cholestasis, sleep apnea, liver failure and worsening of lower urinary tract symptoms from an enlarged prostate. ${ }^{18,19}$ Therefore, the discovery of novel agents as anti-LOH agents is urgently needed.

Testosterone production is regulated by luteinizing hormone (LH) and LH induces cAMP synthesis in Leydig cells by binding to the membrane LH receptors. ${ }^{20}$ cAMP catalyzes the synthesis of PKA, which transports cholesterol from the cytoplasmic pool to mitochondria and promotes steroidogenesis by steroidgenerating enzymes (CYP11A1, 3 $\beta$-HSD) and steroidogenic acute regulatory (StAR) protein ${ }^{21}$ Additionally, autophagy in Leydig cells promotes lipid metabolism and provides sources such as triglycerides (TGs) and cholesterol for testosterone production, which plays an important role in testosterone synthesis. ${ }^{22,23}$

Herein, we report the discovery of a hit compound as testosterone synthesis promoter by screening our small synthetic library of diterpenoid analogs. The methylpyrimidine 
ring-fused diterpene analogue 7 was selected as the hit. Then a series of analogs were synthesized based on the hit and their activities in promoting testosterone production in mouse Leydig TM3 cells were evaluated. Results showed that compound 17 (SH380) was the most potent testosterone synthesis promoter. The mechanism by which the 17 increases testosterone production was preliminary explored.

\section{Results and discussion}

\section{Chemistry}

The methylpyrimidine acyl derivatives 7-14 were synthesized as shown in Scheme 1. Compound 6 was prepared according to our previously reported procedure ${ }^{24,25}$ and details were as follows. Coupling reaction of 6,7-epoxygeranyl acetate with (4methoxybenzyl) magnesium chloride yielded compound $\mathbf{1}, \mathrm{Li}_{2}$ $\mathrm{CuCl}_{4}$ was added as catalyst. Key intermediate 2 was obtained by the cyclization of $\mathbf{1}$ in presence of boron trifluoride etherate, and is a racemate according to the Stork-Eschenmoser hypothesis. ${ }^{26,27}$ Therefore, all the synthesized diterpenoids herein belong to racemates. Compound $\mathbf{3}$ was obtained by oxidation of 2 with 2-iodoxybenzoic acid (IBX). Claisen condensation of 3 with ethyl formate in the presence of $\mathrm{NaH}$ provided compound 4 . Compound 6 was furnished by reaction of 4 with piperidine in EtOH and then condensation with acetamidine hydrochloride. Compound 7-14 were prepared by Friedel-Crafts acylation from $\mathbf{6}$ with various acyl chlorides respectively.

The synthetic route of 2-methylpyrimidine derivatives 15-22 is outlined in Scheme 2. Compound 15 was prepared from 7 with hydroxylamine hydrochloride in the presence of $\mathrm{K}_{2} \mathrm{CO}_{3}$. Condensation of 7 with hydrazine hydrate (85\%) yielded 16 . Reaction of 7 with methylmagnesium chloride yielded 17. Compound 18 was produced by Wolff-Kishner-Huang Min-lon reduction of 7 with hydrazine hydrate (85\%) in the presence of $\mathrm{NaOH}$. Reduction of 7 with sodium borohydride produced compound 19, and 20 was provided by dehydration of 19 with $p$ toluenesulfonic acid. Oxidation of 7 with $\mathrm{CrO}_{3}$ in $\mathrm{AcOH}$ produced 21.

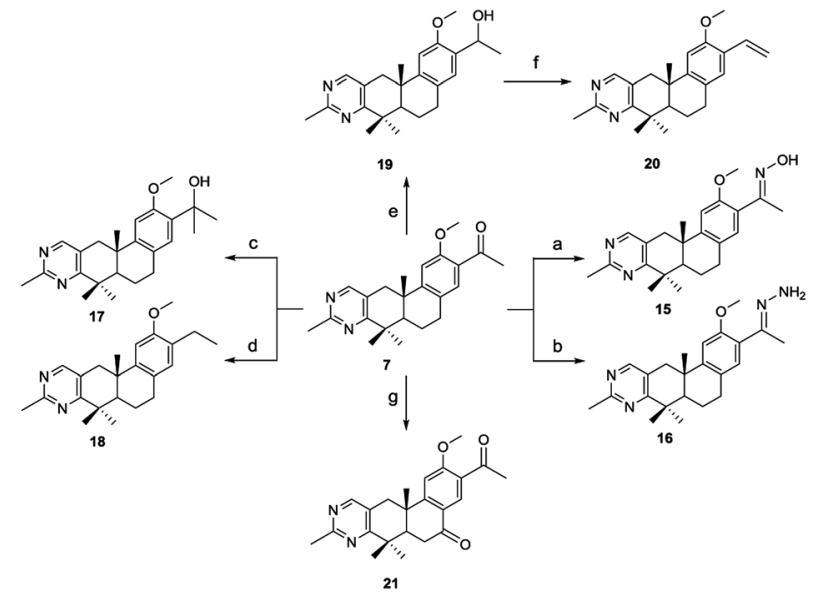

Scheme 2 Reagents and conditions: (a) hydroxylamine hydrochloride, $\mathrm{K}_{2} \mathrm{CO}_{3}$, EtOH, rt; (b) hydrazine hydrate (85\%), $\mathrm{TsOH}, \mathrm{EtOH}$, reflux; (c) methylmagnesium chloride, anhydrous $\mathrm{THF}, 0{ }^{\circ} \mathrm{C}$; (d) hydrazine hydrate (85\%), $\mathrm{NaOH}$, triglycol, $120{ }^{\circ} \mathrm{C}$ to $190{ }^{\circ} \mathrm{C}$; (e) $\mathrm{NaBH}_{4}, \mathrm{DCM}$, $\mathrm{MeOH}, \mathrm{O}^{\circ} \mathrm{C}$; (f) $\mathrm{TsOH}$, anhydrous $\mathrm{THF}, 60{ }^{\circ} \mathrm{C}$; (g) $\mathrm{CrO}_{3}, \mathrm{AcOH}$, rt.

\section{Activity and cytotoxicity evaluation of compound 7 and its derivatives}

A hit was obtained by screening our small synthetic diterpenoids library. Mouse TM3 Leydig cells were treated with each tested compound at concentration of $20 \mu \mathrm{M}$ for $24 \mathrm{~h}$, and the testosterone levels in the culture medium were measured by ELISA (enzyme-linked immuno sorbent assay) kit. Among those analogs, compound 7 (QB364) was determined as a testosterone synthesis promoter with a testosterone concentration of 271.7 $\mu \mathrm{M} \mathrm{L}^{-1}$ and was more potent than the positive icariin. ${ }^{28}$ Therefore, it was selected as the hit compound for further structure-activity relationship (SAR) optimization.

The first-round synthetic compounds 8-14 were obtained by Friedel-Crafts acylation with various acyl chlorides respectively and their activity in promoting testosterone production on mouse Leydig TM3 cells was determined by ELISA kit. As shown in Table 1 , the activity decreased significantly when the acetyl group (7) was replaced by various acyl substituents. Thus,

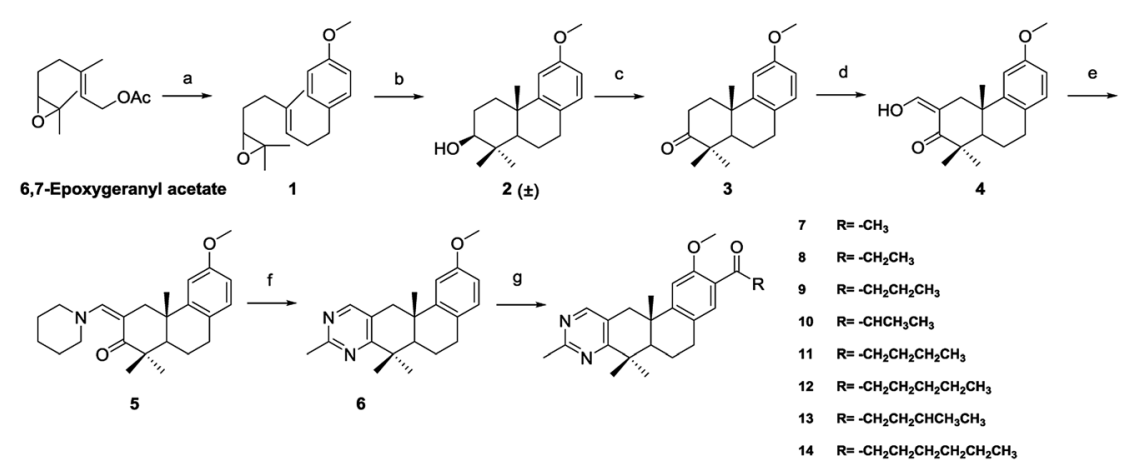

Scheme 1 Reagents and conditions: (a) (4-methoxybenzyl) magnesium chloride, $\mathrm{LiCuCl}_{4}$, anhydrous THF, $0{ }^{\circ} \mathrm{C}$; (b) boron trifluoride etherate, anhydrous $\mathrm{CH}_{2} \mathrm{Cl}_{2},-78{ }^{\circ} \mathrm{C}$; (c) IBX, THF, DMSO, rt; (d) ethyl formate, NaH, anhydrous THF, rt; (e) piperidine, EtOH, reflux; (f) acetamidine hydrochloride, sodium methoxide, $\mathrm{EtOH}$, reflux; (g) acyl chloride, $\mathrm{AlCl}_{3}, \mathrm{DCM}, \mathrm{O}^{\circ} \mathrm{C}$. 
Table 1 Testosterone levels and cytotoxicity of compounds 7-14 in TM3 cells ${ }^{a}$

13

compound 7 was selected for the second-round structure modification.

The second-round synthetic analogs 15-21 were obtained by modification of the acetyl group of 7 and their activity in promoting testosterone production was determined using ELISA kit. The results (Table 2) showed that the activity increased when the carbonyl group of 7 was substituted by oxime (15), while decreased as hydrazine substituent (16) was introduced into. If the carbonyl group of 7 was reduced to hydroxy (19) the activity decreased obviously. To our delight, the testosterone level in TM3 was increased significantly as the acetyl group was replaced by tert-butanol group (17). If the acetyl group was converted to the alkyl substituent such as ethyl (18) or vinyl (20), the activity of testosterone production was also decreased. For derivative modified at the C- 6 and C-7 positions, the activity decreased as the carbonyl (21) substituent was introduced into $\mathrm{C} 7$ position. Further cytotoxicity evaluation in mouse TM3 cells with the SRB assay disclosed that all these analogs showed very little cytotoxicity $\left(\mathrm{IC}_{50}>100 \mu \mathrm{M}\right)$. Considering the above results, the safe compound 17 exhibited most potent activity in promoting testosterone production, thus it was selected for further studies.
Table 2 Testosterone levels and cytotoxicity of compounds 15-21 in TM3 cells ${ }^{a}$

\begin{tabular}{|c|c|c|c|c|}
\hline Compd & $\mathrm{R} 2$ & $\mathrm{R} 3$ & Testosterone Levels $^{b}(\mu \mathrm{M} / \mathrm{L})$ & $\mathrm{IC}_{50}{ }^{c}(\mu \mathrm{M})$ \\
\hline 7 & & - & $271.7 \pm 10.0$ & $>100$ \\
\hline 15 & & - & $282.2 \pm 5.5$ & $>100$ \\
\hline 16 & & - & $188.5 \pm 5.5$ & $>100$ \\
\hline 17 & & - & $303.5 \pm 5.5$ & $>100$ \\
\hline 18 & - & - & $237.0 \pm 4.0$ & $>100$ \\
\hline 19 & & - & $222.8 \pm 7.0$ & $>100$ \\
\hline 20 & -2 & - & $227.1 \pm 3.0$ & $>100$ \\
\hline 1 & & $\mathrm{O}$ & $259.5 \pm 6.5$ & $>100$ \\
\hline
\end{tabular}

${ }^{a}$ See Experimental section. ${ }^{b}$ Testosterone levels in the culture medium are measured by ELISA kit; data are expressed as mean \pm SD of three independent assays. ${ }^{c}$ Activities of compounds against the growth of TM3 cells are detected with the SRB assay and their IC $_{50}$ data are an average of at least three independent experiments.

Table $3 \quad I C_{50}$ of compound 24 against the growth of various normal cells ${ }^{a}$

\begin{tabular}{llllll}
\hline & $\begin{array}{l}\text { Leydig } \\
\text { cell }\end{array}$ & \multicolumn{2}{c}{ Normal cell $^{b}$} & & \\
\hline Cell line & TM3 & HAF & NCM460 & L-02 & PTN1A \\
IC $_{50}(\mu \mathrm{M})^{c}$ & $112.6^{d}$ & $111.8^{d}$ & $>200$ & $>200$ & $>200$
\end{tabular}

${ }^{a}$ See Experimental section. ${ }^{b}$ HAF, human fibroblast cell line; NCM460, human colon mucosal epithelial cell line; L-02, human fetal hepatocyte cell line; PTN1A, human prostate epithelial cell line. ${ }^{c}$ Various cells were treated with indicated concentrations of compound 17 for $24 \mathrm{~h}$; cell proliferation was determined by SRB assay; data were expressed as $\mathrm{IC}_{50}$ of three independent assays. ${ }^{d}$ Variation $\pm 10 \%$.

\section{Compound 17 has little cytotoxicity on TM3 and other normal cells within the effective concentrations}

To further determination of the in vitro safety of 17 , we detected its cytotoxicity in TM3 and several human normal cells including NCM460, HAF, L-02 and PTN1A by SRB assay. As shown in Table 3, compound $\mathbf{1 7}$ showed very little toxicity on cell proliferation of $\mathrm{TM} 3\left(\mathrm{IC}_{50}=112.6 \mu \mathrm{M}\right)$ and $\mathrm{HAF}\left(\mathrm{IC}_{50}=\right.$ $112.6 \mu \mathrm{M})$ cells. In addition, 17 has almost no toxic effects on NCM460, L-02 and PTN1A cells ( $\left.\mathrm{IC}_{50}>200 \mu \mathrm{M}\right)$. Therefore, compound 17 is a safe compound in vitro. 

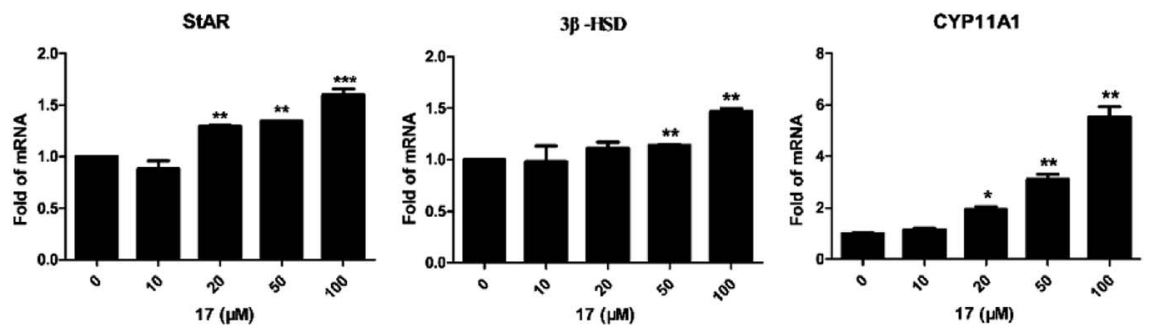

Fig. 1 Compound 17 advanced the mRNA expression levels of testosterone synthetase in Leydig cells. ${ }^{a}$ See Experimental section. Mouse Leydig TM3 cells were treated with different concentrations of compound 17 for $24 \mathrm{~h}$. mRNA levels of steroidogenesis-related genes StAR, $3 \beta$-HSD and CYP11A1 were measured by quantitative-PCR. Data were expressed as mean \pm SD of three independent assays; Student's $t$-tests were performed; *p $<0.05, * * p<0.01, * * * p<0.001$.

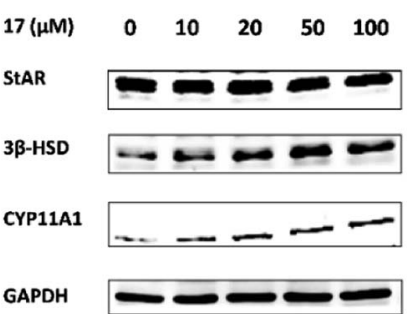

Fig. 2 Compound 17 advanced the protein expression levels of testosterone synthetase in Leydig cells. ${ }^{a}$ a See Experimental section. Mouse Leydig TM3 cells were treated with different concentrations of

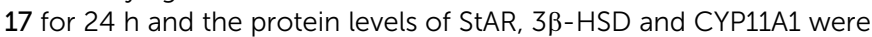
measured by Western blotting. GAPDH was used as a control.

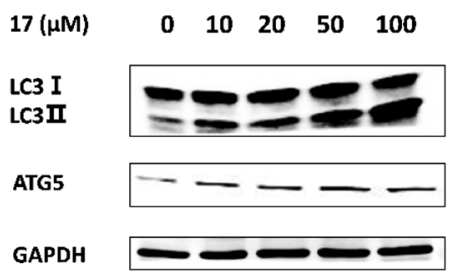

Fig. 3 Compound 17 promotes the autophagy-related protein expression levels in TM3 cells. ${ }^{a}$ a See Experimental section. Mouse Leydig TM3 cells were treated with different concentrations of 17 for $24 \mathrm{~h}$. The expression of LC3 I/II and ATG5 were detected by western blotting. GAPDH was used as a control.

\section{Compound 17 enhanced the expression of testosterone synthesis-regulating gens}

For determination of the primary mechanism of $\mathbf{1 7}$ on testosterone synthesis, the mRNA and protein expression levels of testosterone synthetase, including StAR, 3 $\beta$-HSD and CYP11A1 were analyzed. The qPCR analysis showed that the mRNA expression levels of StAR, $3 \beta$-HSD and CYP11A1 were increased significantly in a concentration-dependent manner (Fig. 1). Furthermore, the protein expression levels of the three key enzymes in TM3 cells were validated by western blotting. Results indicated that $\mathbf{1 7}$ also increased the protein expression levels of StAR, 3 $\beta$-HSD and CYP11A1 obviously as the concentration rised from $10 \mu \mathrm{M}$ to $100 \mu \mathrm{M}$ (Fig. 2). These primary mechanism studies indicated that $\mathbf{1 7}$ increased testosterone levels in Leydig cells via promoting testosterone synthesis.

\section{Compound 17 regulates the expression of autophagy-related proteins in Leydig cells}

Autophagy dysfunction played a key role in the loss of testosterone production in some LOH patients. ${ }^{21}$ Therefore, we tried to identify if $\mathbf{1 7}$ promoted testosterone production via induction of autophagy. LC3-II serves as a reliable marker for mature autophagosomes and ATG5 is a gene product required for the formation of autophagosomes. We assessed the levels of the autophagy-related proteins by western blotting. As shown in Fig. 3, the expressions of ATG5, LC3-II and the ratio of LC3-II/ LC3-I were increased significantly after treatment with 17 . It suggested that the compound could promoted testosterone synthesis via activating autophagy in Leydig cells.

\section{Conclusions}

In this study, we designed and synthesized a number of 15 methylpyrimidine ring-fused tricyclic diterpene analogs. Most of the derivatives showed potent activity in promoting testosterone production in mouse Leydig TM3 cells, which was much better than that of the positive control icariin. Among these analogs, compound 17 exhibited the most potent activity and almost no toxic effect. Preliminary mechanism studies indicated that $\mathbf{1 7}$ could significantly enhance the expression of testosterone synthesis-related marker genes (StAR, 3 3 -HSD and CYP11A1) in a concentration-dependent manner. Further studies disclosed that $\mathbf{1 7}$ could also stimulate autophagy in Leydig cells and promote the expression of autophagy-related genes (LC3 and ATG 5). In conclusion, compound 17 was discovered as a promising compound, which could be further developed as a potential therapeutic agent for LOH.

\section{Experimental section}

\section{Chemistry}

General methods. Unless otherwise specified, starting materials, reagents, and solvents were purchased from commercial suppliers and used without further purification. Anhydrous THF was obtained by distillation over sodium wire. 
All non-aqueous reactions were run under a nitrogen atmosphere and all reaction vessels were oven-dried. Thin-layer chromatography (TLC) was performed on silica gel plates (QingDao) with a layer thickness of $0.25 \mathrm{~mm}$ and spots were visualized by their quenching of the fluorescence of an indicator admixed to the $\mathrm{SiO}_{2}$ layer. Column chromatographic purification was carried out using silica gel (200-300 mesh) and an EtOAc/hexane mixture or gradient was used unless otherwise stated. ${ }^{1} \mathrm{H}$ and ${ }^{13} \mathrm{C}$ NMR spectra were recorded on a Bruker Advance III 400 spectrometer at $400 \mathrm{MHz}\left({ }^{1} \mathrm{H}\right)$ and $100 \mathrm{MHz}$ $\left({ }^{13} \mathrm{C}\right)$. Chemical shifts are reported in $\delta$ (ppm) using the $\delta 0$ signal of tetramethylsilane (TMS) as internal standards. High resolution mass spectra were performed using a Bruker ESI-TOF high-resolution mass spectrometer.

General procedure for the Friedel-Crafts acylation (method A). To a solution of compound 6 (100 $\mathrm{mg}, 0.27 \mathrm{mmol})$ in anhydrous $\mathrm{CH}_{2} \mathrm{Cl}_{2}(20 \mathrm{~mL})$ was added anhydrous $\mathrm{AlCl}_{3}(108 \mathrm{mg}$, $0.81 \mathrm{mmol})$ and respective acyl chloride $(0.54 \mathrm{mmol})$ at $0{ }^{\circ} \mathrm{C}$ under nitrogen. Then reaction mixture was stirred for $2 \mathrm{~h}$ at room temperature. After that the mixture was poured into water $(50 \mathrm{~mL})$ and extracted with $\mathrm{CH}_{2} \mathrm{Cl}_{2}(10 \mathrm{~mL} \times 3)$. The organic layer was washed with brine, dried over anhydrous $\mathrm{Na}_{2} \mathrm{SO}_{4}$, and concentrated under vacuum. The residue was purified by silica gel chromatography to afford the product.

General procedure for the reduction reaction (method $B$ ). $\mathrm{NaBH}_{4}$ (3 mmol) was added into a solution of compound 7 or 21 $(0.3 \mathrm{mmol})$ in anhydrous $\mathrm{CH}_{2} \mathrm{Cl}_{2}(10 \mathrm{~mL})$ and $\mathrm{MeOH}(10 \mathrm{~mL})$ with ice cooling under nitrogen. After stirring for $1 \mathrm{~h}$ at room temperature, the reaction was quenched by saturated aqueous $\mathrm{NH}_{4} \mathrm{Cl}$ solution with ice cooling. The mixture was extracted with EtOAc $(20 \mathrm{~mL} \times 3)$. The organic layer was washed with brine, dried over $\mathrm{Na}_{2} \mathrm{SO}_{4}$ and concentrated under vacuum. The residue was purified by silica gel chromatography to give the product.

General procedure for the oxidation reaction (method $\mathrm{C}$ ). $\mathrm{CrO}_{3}(0.6 \mathrm{mmol})$ was added into a solution of compound 6 (0.3 $\mathrm{mmol})$ in $\mathrm{AcOH}(10 \mathrm{~mL})$ with ice cooling. After stirring for $3 \mathrm{~h}$ at room temperature, the mixture was poured into water $(50 \mathrm{~mL})$ and extracted with EtOAc $(20 \mathrm{~mL} \times 3)$. The organic layer was washed with sodium bicarbonate solution (5\%) and brine, dried over anhydrous $\mathrm{Na}_{2} \mathrm{SO}_{4}$, and concentrated under vacuum. The residue was purified by silica gel chromatography to give the product.

General procedure for the Wolff-Kishner-Huang Min-lon reduction (method D). Hydrazine hydrate (85\%) (1.2 mmol) was added into a stirred solution of compound $7(0.3 \mathrm{mmol})$ in triglycol $(10 \mathrm{~mL})$ under nitrogen. The reaction mixture was stirred for $1 \mathrm{~h}$ at $120^{\circ} \mathrm{C}$. Then removed the condensing tube and heated the mixture to $190^{\circ} \mathrm{C}$. After the temperature is stable, the condensing tube was reinstalled and mixture was stirred for $3 \mathrm{~h}$ at $190{ }^{\circ} \mathrm{C}$. After cooling, the mixture was poured into water (40 $\mathrm{mL})$ and extracted with EtOAc $(15 \mathrm{~mL} \times 3)$. The organic layer was washed with brine, dried over anhydrous $\mathrm{Na}_{2} \mathrm{SO}_{4}$, and concentrated. The residue was purified by silica gel chromatography to give the product.

General procedure for the dehydration reaction (method E). To a solution of compound 19 or $22(0.3 \mathrm{mmol})$ in anhydrous EtOH $(10 \mathrm{~mL})$ was added $\mathrm{TsOH}(0.6 \mathrm{mmol})$ under nitrogen. The reaction mixture was stirred for $6 \mathrm{~h}$ under reflux. Then the mixture was poured into water $(30 \mathrm{~mL})$ and extracted with EtOAc $(10 \mathrm{~mL} \times 3)$. The organic layer was washed with sodium bicarbonate solution (5\%) and brine, dried over anhydrous $\mathrm{Na}_{2} \mathrm{SO}_{4}$, and concentrated under vacuum. The residue was purified by silica gel chromatography to give the product.

Compound 7. This compound was obtained from compound 6 employing method A. White solid. Yield 92\%. ${ }^{1} \mathrm{H}$ NMR (400 $\left.\mathrm{MHz} \mathrm{CDCl}_{3}\right) \delta 8.39(\mathrm{~s}, 1 \mathrm{H}), 7.49(\mathrm{~s}, 1 \mathrm{H}), 6.93(\mathrm{~s}, 1 \mathrm{H}), 3.94(\mathrm{~s}, 3 \mathrm{H})$, $3.16(\mathrm{~d}, J=15.5 \mathrm{~Hz}, 1 \mathrm{H}), 2.98-2.93(\mathrm{~m}, 1 \mathrm{H}), 2.85-2.75(\mathrm{~m}, 2 \mathrm{H})$, $2.69(\mathrm{~s}, 3 \mathrm{H}), 2.60(\mathrm{~s}, 3 \mathrm{H}), 2.03-1.96(\mathrm{~m}, 1 \mathrm{H}), 1.85(\mathrm{~d}, J=12.3 \mathrm{~Hz}$, $1 \mathrm{H}), 1.78-1.71(\mathrm{~m}, 1 \mathrm{H}), 1.36(\mathrm{~s}, 3 \mathrm{H}), 1.34(\mathrm{~s}, 3 \mathrm{H}), 1.16(\mathrm{~s}, 3 \mathrm{H}) .{ }^{13} \mathrm{C}$ NMR (100 MHz, $\left.\mathrm{CDCl}_{3}\right) \delta 199.41,172.09,166.09,157.62,157.34$, $151.81,131.11,127.87,126.34,123.29,108.57,55.57,49.14$, $40.65,39.69,37.52,31.79,31.22,30.12$, 25.82, 23.96, 23.16, 20.44. HRMS (ESI): calcd for $\mathrm{C}_{23} \mathrm{H}_{29} \mathrm{~N}_{2} \mathrm{O}_{2}[\mathrm{M}+\mathrm{H}]^{+}, 365.2224$; found, 365.2233.

Compound 8. This compound was obtained from compound 6 employing method A. White solid. Yield 90\%. ${ }^{1} \mathrm{H}$ NMR (400 $\left.\mathrm{MHz} \mathrm{CDCl}_{3}\right) \delta 8.38(\mathrm{~s}, 1 \mathrm{H}), 7.44(\mathrm{~s}, 1 \mathrm{H}), 6.92(\mathrm{~s}, 1 \mathrm{H}), 3.92(\mathrm{~s}, 3 \mathrm{H})$, $3.16(\mathrm{~d}, J=15.5 \mathrm{~Hz}, 1 \mathrm{H}), 3.00-2.93(\mathrm{~m}, 3 \mathrm{H}), 2.85-2.75(\mathrm{~m}, 2 \mathrm{H})$, 2.69 (s, 3H), 2.00-1.96 (m, 1H), 1.85 (d, $J=12.4$ Hz, 1H), 1.78$1.71(\mathrm{~m}, 1 \mathrm{H}), 1.36(\mathrm{~s}, 3 \mathrm{H}), 1.33(\mathrm{~s}, 3 \mathrm{H}), 1.16-1.13(\mathrm{~m}, 6 \mathrm{H}) .{ }^{13} \mathrm{C}$ NMR (100 MHz, $\left.\mathrm{CDCl}_{3}\right) \delta 203.11,172.21,166.11,157.64,156.97$, $151.25,131.00,127.94,126.64,123.42,108.59$, 55.65, 49.22, 40.72 , 39.75, 37.52, 36.95, 31.27, 30.20, 25.84, 24.02, 23.21, 20.50, 8.48. HRMS (ESI): calcd for $\mathrm{C}_{24} \mathrm{H}_{31} \mathrm{~N}_{2} \mathrm{O}_{2}[\mathrm{M}+\mathrm{H}]^{+}$, 379.2380; found, 379.2384 .

Compound 9. This compound was obtained from compound 6 employing method A. White solid. Yield 87\%. ${ }^{1} \mathrm{H}$ NMR (400 $\left.\mathrm{MHz} \mathrm{CDCl}_{3}\right) \delta 8.40(\mathrm{~s}, 1 \mathrm{H}), 7.42(\mathrm{~s}, 1 \mathrm{H}), 6.93(\mathrm{~s}, 1 \mathrm{H}), 3.93(\mathrm{~s}, 3 \mathrm{H})$, $3.17(\mathrm{~d}, J=15.6 \mathrm{~Hz}, 1 \mathrm{H}), 2.99-2.92(\mathrm{~m}, 3 \mathrm{H}), 2.86-2.76(\mathrm{~m}, 2 \mathrm{H})$, $2.70(\mathrm{~s}, 3 \mathrm{H}), 2.02-1.97(\mathrm{~m}, 1 \mathrm{H}), 1.87$ (d, $J=12.5 \mathrm{~Hz}, 1 \mathrm{H}), 1.80-$ $1.76(\mathrm{~m}, 1 \mathrm{H}), 1.73-1.68(\mathrm{~m}, 2 \mathrm{H}), 1.38(\mathrm{~s}, 3 \mathrm{H}), 1.35(\mathrm{~s}, 3 \mathrm{H}), 1.17(\mathrm{~s}$, $3 \mathrm{H}), 0.97(\mathrm{t}, J=7.4 \mathrm{~Hz}, 3 \mathrm{H}) .{ }^{13} \mathrm{C} \mathrm{NMR}\left(100 \mathrm{MHz}, \mathrm{CDCl}_{3}\right.$ ) $\delta$ 202.65, 172.22, 166.17, 157.66, 156.89, 151.18, 130.93, 128.00, 127.08, 123.37, 108.65, 55.68, 49.29, 45.67, 40.78, 39.76, 37.54, $31.29,30.22,25.85,24.01,23.21,20.53,17.86,13.95$. HRMS (ESI): calcd for $\mathrm{C}_{25} \mathrm{H}_{33} \mathrm{~N}_{2} \mathrm{O}_{2}[\mathrm{M}+\mathrm{H}]^{+}$, 393.2537; found, 393.2560.

Compound 10. This compound was obtained from compound 6 employing method A. White solid. Yield $88 \% .{ }^{1} \mathrm{H}$ NMR (400 MHz, $\left.\mathrm{CDCl}_{3}\right) \delta 8.39$ (s, 1H), 7.29 (s, 1H), $6.91(\mathrm{~s}, 1 \mathrm{H})$, 3.91 (s, 3H), 3.53-3.46 (m, 1H), 3.16 (d, $J=15.5 \mathrm{~Hz}, 1 \mathrm{H}), 2.97-$ $2.93(\mathrm{~m}, 1 \mathrm{H}), 2.85-2.76(\mathrm{~m}, 2 \mathrm{H}), 2.70(\mathrm{~s}, 3 \mathrm{H}), 1.99$ (dd, $J=12.2$, $4.5 \mathrm{~Hz}, 1 \mathrm{H}), 1.86(\mathrm{~d}, J=12.3 \mathrm{~Hz}, 1 \mathrm{H}), 1.79-1.73(\mathrm{~m}, 1 \mathrm{H}), 1.37$ (s, $3 \mathrm{H}), 1.34$ (s, 3H), 1.16-1.13 (m, 9H). ${ }^{13} \mathrm{C} \mathrm{NMR} \mathrm{(100} \mathrm{MHz,} \mathrm{CDCl}_{3}$ ) $\delta 207.69,172.18,166.09,157.63,156.24,150.62,130.84,127.96$, 127.07, 123.40, 108.42, 55.68, 49.20, 40.72, 39.94, 39.71, 37.45, $31.25,30.18,25.85,24.00,23.18,20.47,18.68$, 18.55. HRMS (ESI): calcd for $\mathrm{C}_{25} \mathrm{H}_{33} \mathrm{~N}_{2} \mathrm{O}_{2}[\mathrm{M}+\mathrm{H}]^{+}$, 393.2537; found, 393.2557.

Compound 11. This compound was obtained from compound 6 employing method A. White solid. Yield $82 \% .{ }^{1} \mathrm{H}$ NMR (400 MHz, $\mathrm{CDCl}_{3}$ ) $\delta 8.39$ (s, 1H), 7.41 (s, 1H), $6.92(\mathrm{~s}, 1 \mathrm{H})$, $3.92(\mathrm{~s}, 3 \mathrm{H}), 3.16$ (d, $J=15.5 \mathrm{~Hz}, 1 \mathrm{H}), 2.97-2.93(\mathrm{~m}, 3 \mathrm{H}), 2.85-$ $2.76(\mathrm{~m}, 2 \mathrm{H}), 2.70(\mathrm{~s}, 3 \mathrm{H}), 1.98(\mathrm{dd}, J=12.4,5.1 \mathrm{~Hz}, 1 \mathrm{H}), 1.85$ (d, $J=12.4 \mathrm{~Hz}, 1 \mathrm{H}), 1.79-1.71(\mathrm{~m}, 1 \mathrm{H}), 1.68-1.61$ (m, 2H), 1.41-1.39 $(\mathrm{m}, 2 \mathrm{H}), 1.37(\mathrm{~s}, 3 \mathrm{H}), 1.34(\mathrm{~s}, 3 \mathrm{H}), 1.16(\mathrm{~s}, 3 \mathrm{H}), 0.92(\mathrm{t}, J=7.3 \mathrm{~Hz}$, 
3H). ${ }^{13} \mathrm{C}$ NMR (100 MHz, $\left.\mathrm{CDCl}_{3}\right) \delta$ 202.85, 172.13, 166.09, $157.63,156.79,151.14,130.91,127.92$, 126.93, 123.35, 108.53, $55.61,49.18,43.42,40.69,39.70,37.48,31.24,30.16,26.53$, 25.84, 23.98, 23.17, 22.51, 20.46, 13.97. HRMS (ESI): calcd for $\mathrm{C}_{26} \mathrm{H}_{35} \mathrm{~N}_{2} \mathrm{O}_{2}[\mathrm{M}+\mathrm{H}]^{+}$, 407.2693; found, 407.2692.

Compound 12. This compound was obtained from compound 6 employing method A. White solid. Yield $84 \% .{ }^{1} \mathrm{H}$ NMR $\left(400 \mathrm{MHz}, \mathrm{CDCl}_{3}\right) \delta 8.40(\mathrm{~s}, 1 \mathrm{H}), 7.42(\mathrm{~s}, 1 \mathrm{H}), 6.92(\mathrm{~s}, 1 \mathrm{H})$, 3.93 (s, 3H), 3.17 (d, $J=15.5 \mathrm{~Hz}, 1 \mathrm{H}), 2.99-2.93(\mathrm{~m}, 3 \mathrm{H}), 2.86-$ $2.76(\mathrm{~m}, 2 \mathrm{H}), 2.70(\mathrm{~s}, 3 \mathrm{H}), 1.99(\mathrm{dd}, J=12.7,5.8 \mathrm{~Hz}, 1 \mathrm{H}), 1.86(\mathrm{~d}$, $J=12.3 \mathrm{~Hz}, 1 \mathrm{H}), 1.80-1.65(\mathrm{~m}, 5 \mathrm{H}), 1.37$ (s, 2H), $1.35(\mathrm{~s}, 6 \mathrm{H})$, $1.17(\mathrm{~s}, 3 \mathrm{H}), 0.90(\mathrm{t}, J=6.9 \mathrm{~Hz}, 3 \mathrm{H}) .{ }^{13} \mathrm{C} \mathrm{NMR}\left(100 \mathrm{MHz}, \mathrm{CDCl}_{3}\right)$ $\delta 202.86,172.15,166.10,157.64,156.81,151.15,130.93,127.93$, 126.93, 123.36, 108.54, 55.62, 49.19, 43.70, 40.70, 39.71, 37.49, $31.63,31.25,30.17,25.85,24.11,23.99,23.18,22.53,20.47$, 14.00. HRMS (ESI): calcd for $\mathrm{C}_{27} \mathrm{H}_{37} \mathrm{~N}_{2} \mathrm{O}_{2}[\mathrm{M}+\mathrm{H}]^{+}, 421.2850$; found, 421.2858 .

Compound 13. This compound was obtained from compound 6 employing method A. White solid. Yield 91\%. ${ }^{1} \mathrm{H}$ NMR (400 MHz, $\left.\mathrm{CDCl}_{3}\right) \delta 8.40(\mathrm{~s}, 1 \mathrm{H}), 7.41(\mathrm{~s}, 1 \mathrm{H}), 6.92(\mathrm{~s}, 1 \mathrm{H})$, 3.93 (s, 3H), 3.17 (d, $J=15.5 \mathrm{~Hz}, 1 \mathrm{H}), 2.97-2.94(\mathrm{~m}, 3 \mathrm{H}), 2.86-$ $2.76(\mathrm{~m}, 2 \mathrm{H}), 2.70$ (s, 3H), 1.99 (dd, $J=12.8,5.4 \mathrm{~Hz}, 1 \mathrm{H}), 1.86$ (d, $J=12.5 \mathrm{~Hz}, 1 \mathrm{H}), 1.80-1.72$ (m, 1H), $1.63-1.61$ (m, 1H), 1.59-1.53 $(\mathrm{m}, 2 \mathrm{H}), 1.37(\mathrm{~s}, 3 \mathrm{H}), 1.35(\mathrm{~s}, 3 \mathrm{H}), 1.17(\mathrm{~s}, 3 \mathrm{H}), 0.92(\mathrm{~d}, J=8.1 \mathrm{~Hz}$, $6 \mathrm{H}) .{ }^{13} \mathrm{C}$ NMR $\left(100 \mathrm{MHz}, \mathrm{CDCl}_{3}\right) \delta$ 203.12, 172.17, 166.11, 157.63, 156.76, 151.16, 130.97, 127.96, 126.94, 123.38, 108.53, $55.60,49.20,41.80,40.71,39.73,37.50,33.33,31.26,30.18$, 27.94, 25.85, 24.00, 23.19, 22.48 (2C), 20.48. HRMS (ESI): calcd for $\mathrm{C}_{27} \mathrm{H}_{37} \mathrm{~N}_{2} \mathrm{O}_{2}[\mathrm{M}+\mathrm{H}]^{+}$, 421.2850; found, 421.2876.

Compound 14. This compound was obtained from compound 6 employing method A. White solid. Yield $80 \% .{ }^{1} \mathrm{H}$ NMR (400 MHz, $\left.\mathrm{CDCl}_{3}\right) \delta 8.40(\mathrm{~s}, 1 \mathrm{H}), 7.41(\mathrm{~s}, 1 \mathrm{H}), 6.92(\mathrm{~s}, 1 \mathrm{H})$, 3.93 (s, 3H), 3.17 (d, $J=15.4 \mathrm{~Hz}, 1 \mathrm{H}), 2.99-2.93(\mathrm{~m}, 3 \mathrm{H}), 2.86-$ $2.76(\mathrm{~m}, 2 \mathrm{H}), 2.70(\mathrm{~s}, 3 \mathrm{H}), 1.99(\mathrm{dd}, J=12.5,5.2 \mathrm{~Hz}, 1 \mathrm{H}), 1.86(\mathrm{~d}$, $J=12.3 \mathrm{~Hz}, 1 \mathrm{H}), 1.79-1.73(\mathrm{~m}, 1 \mathrm{H}), 1.68-1.64(\mathrm{~m}, 2 \mathrm{H}), 1.37$ (s, $3 \mathrm{H}), 1.34(\mathrm{~s}, 6 \mathrm{H}), 1.31(\mathrm{~s}, 3 \mathrm{H}), 1.17(\mathrm{~s}, 3 \mathrm{H}), 0.88(\mathrm{t}, J=6.4 \mathrm{~Hz}$, $3 \mathrm{H}) .{ }^{13} \mathrm{C}$ NMR $\left(100 \mathrm{MHz}, \mathrm{CDCl}_{3}\right) \delta 202.88,172.18,166.10$, 157.62 , 156.81, 151.14, 130.93, 127.94, 126.96, 123.38, 108.55, $55.63,49.21,43.75,40.71,39.73,37.49,31.70,31.26,30.18$, $29.11,25.84,24.40,24.00,23.19,22.54,20.48$, 14.06. HRMS (ESI): calcd for $\mathrm{C}_{28} \mathrm{H}_{39} \mathrm{~N}_{2} \mathrm{O}_{2}[\mathrm{M}+\mathrm{H}]^{+}$, 435.3006; found, 435.3025.

Compound 15. To a solution of compound 7 (100 mg, 0.27 $\mathrm{mmol})$ in anhydrous EtOH $(10 \mathrm{~mL})$ was added hydroxylamine hydrochloride (38 mg, $0.54 \mathrm{mmol})$ and $\mathrm{K}_{2} \mathrm{CO}_{3}(151 \mathrm{mg}, 1.10$ $\mathrm{mmol})$. After stirring for $12 \mathrm{~h}$ at room temperature, the mixture was poured into water $(50 \mathrm{~mL})$ and extracted with DCM $(20 \mathrm{~mL}$ $\times 3$ ). The organic layer was washed with brine, dried over anhydrous $\mathrm{Na}_{2} \mathrm{SO}_{4}$, and concentrated under vacuum. The residue was purified by silica gel chromatography (petroleum ether/EtOAc, 2/1, v/v) to afford compound 15 (64 mg, 65\%) as a white solid. ${ }^{1} \mathrm{H}$ NMR (400 MHz, $\left.\mathrm{CDCl}_{3}\right) \delta 8.40(\mathrm{~s}, 1 \mathrm{H}), 7.04(\mathrm{~s}$, $1 \mathrm{H}), 6.89(\mathrm{~s}, 1 \mathrm{H}), 3.87(\mathrm{~s}, 3 \mathrm{H}), 3.17$ (d, J=15.6 Hz, 1H), 2.96-2.91 (m, 1H), 2.86-2.75 (m, 2H), $2.71(\mathrm{~s}, 3 \mathrm{H}), 2.24$ (s, 3H), 1.97 (dd, $J$ $=12.7,5.8 \mathrm{~Hz}, 1 \mathrm{H}), 1.86(\mathrm{~d}, J=12.4 \mathrm{~Hz}, 1 \mathrm{H}), 1.80-1.72(\mathrm{~m}, 1 \mathrm{H})$, $1.37(\mathrm{~s}, 3 \mathrm{H}), 1.35(\mathrm{~s}, 3 \mathrm{H}), 1.16(\mathrm{~s}, 3 \mathrm{H}) .{ }^{13} \mathrm{C} \mathrm{NMR}\left(100 \mathrm{MHz}, \mathrm{CDCl}_{3}\right)$ $\delta 172.39,166.00,157.57,157.13,155.91,147.70,129.90,127.74$, 125.16, 123.64, 108.29, 55.70, 49.39, 40.85, 39.72, 37.25, 31.27,
30.26, 25.79, 24.05, 23.17, 20.54, 15.16. HRMS (ESI): calcd for $\mathrm{C}_{23} \mathrm{H}_{30} \mathrm{~N}_{3} \mathrm{O}_{2}[\mathrm{M}+\mathrm{H}]^{+}$, 380.2333; found, 380.2311.

Compound 16. To a solution of compound 7 (109 mg, 0.30 $\mathrm{mmol})$ in anhydrous EtOH $(10 \mathrm{~mL})$ was added $\mathrm{TsOH}(63 \mathrm{mg}$, $0.33 \mathrm{mmol}$ ) and hydrazine hydrate $(85 \%, 0.03 \mathrm{~mL}, 0.6 \mathrm{mmol})$. After stirring for $6 \mathrm{~h}$ under reflux, the mixture was poured into water $(50 \mathrm{~mL})$ and $\mathrm{pH}$ was adjusted to 9 with sodium bicarbonate solution. Then the mixture was extracted with DCM $(20 \mathrm{~mL} \times 3)$. The organic layer was washed with brine, dried over anhydrous $\mathrm{Na}_{2} \mathrm{SO}_{4}$, and concentrated under vacuum. The residue was purified by silica gel chromatography (petroleum ether/EtOAc, 1/1, v/v) to afford compound $16(85 \mathrm{mg}, 75 \%)$ as a white solid. ${ }^{1} \mathrm{H}$ NMR $\left(400 \mathrm{MHz}, \mathrm{CDCl}_{3}\right) \delta 8.40(\mathrm{~s}, 1 \mathrm{H}), 7.29(\mathrm{~s}$, $1 \mathrm{H}), 6.92(\mathrm{~s}, 1 \mathrm{H}), 3.90(\mathrm{~s}, 3 \mathrm{H}), 3.19(\mathrm{~d}, J=15.6 \mathrm{~Hz}, 1 \mathrm{H}), 3.00-2.96$ (m, 1H), 2.89-2.77 (m, 2H), $2.71(\mathrm{~s}, 3 \mathrm{H}), 2.22$ (s, 3H), 1.99 (dd, $J$ $=12.5,5.5 \mathrm{~Hz}, 1 \mathrm{H}), 1.88(\mathrm{~d}, J=12.4 \mathrm{~Hz}, 1 \mathrm{H}), 1.82-1.74(\mathrm{~m}, 1 \mathrm{H})$, $1.61(\mathrm{~s}, 2 \mathrm{H}), 1.38(\mathrm{~s}, 3 \mathrm{H}), 1.36(\mathrm{~s}, 3 \mathrm{H}), 1.18$ (s, 3H). ${ }^{13} \mathrm{C}$ NMR $(100$ $\left.\mathrm{MHz}, \mathrm{CDCl}_{3}\right) \delta 172.36,165.98,158.51,157.59,156.13,147.71$, $130.01,127.89,127.85,123.67,108.49$, 55.81, 49.42, 40.88, 39.72 , 37.28, 31.28, 30.33, 25.81, 24.08, 23.18, 20.59, 18.78 . HRMS (ESI): calcd for $\mathrm{C}_{23} \mathrm{H}_{31} \mathrm{~N}_{4} \mathrm{O}[\mathrm{M}+\mathrm{H}]^{+}, 379.2492$; found, 379.2468 .

Compound 17. To a solution of compound 7 (109 mg, 0.30 $\mathrm{mmol})$ in anhydrous THF (15 mL) was added methylmagnesium chloride dropwise at $0{ }^{\circ} \mathrm{C}$ under nitrogen. After stirring for $6 \mathrm{~h}$ at room temperature, the reaction was quenched by saturated aqueous $\mathrm{NH}_{4} \mathrm{Cl}$ solution with ice cooling. The mixture was extracted with EtOAc $(20 \mathrm{~mL} \times 3)$. The organic layer was washed with brine, dried over $\mathrm{Na}_{2} \mathrm{SO}_{4}$ and concentrated under vacuum. The residue was purified by silica gel chromatography (petroleum ether/EtOAc, 5/1, v/v) to afford compound 17 (98 mg, 86\%) as white solid. ${ }^{1} \mathrm{H}$ NMR $\left(400 \mathrm{MHz}, \mathrm{CDCl}_{3}\right) \delta 8.39(\mathrm{~s}, 1 \mathrm{H}), 7.01(\mathrm{~s}$, $1 \mathrm{H}), 6.89(\mathrm{~s}, 1 \mathrm{H}), 4.16(\mathrm{~s}, 1 \mathrm{H}), 3.95(\mathrm{~s}, 3 \mathrm{H}), 3.15(\mathrm{~d}, J=15.5 \mathrm{~Hz}$, $1 \mathrm{H}), 2.94-2.81(\mathrm{~m}, 2 \mathrm{H}), 2.76(\mathrm{~d}, J=15.5 \mathrm{~Hz}, 1 \mathrm{H}), 2.70(\mathrm{~s}, 3 \mathrm{H})$, $1.98(\mathrm{dd}, J=12.6,5.8 \mathrm{~Hz}, 1 \mathrm{H}), 1.86$ (d, $J=12.4 \mathrm{~Hz}, 1 \mathrm{H}), 1.80$ $1.73(\mathrm{~m}, 1 \mathrm{H}), 1.60(\mathrm{~d}, J=2.8 \mathrm{~Hz}, 6 \mathrm{H}), 1.37$ (s, 3H), $1.34(\mathrm{~s}, 3 \mathrm{H})$, $1.15(\mathrm{~s}, 3 \mathrm{H}) .{ }^{13} \mathrm{C} \mathrm{NMR}\left(100 \mathrm{MHz}, \mathrm{CDCl}_{3}\right) \delta 172.30,165.98$, 157.60, 155.40, 145.33, 133.94, 127.68, 126.45, 123.65, 108.27, $72.24,55.41,49.39,40.85,39.66,36.94,31.25,30.56,29.76$, 29.69, 25.83, 24.05, 23.14, 20.63. HRMS (ESI): calcd for $\mathrm{C}_{24} \mathrm{H}_{33} \mathrm{~N}_{2} \mathrm{O}_{2}[\mathrm{M}+\mathrm{H}]^{+}$, 381.2537; found, 381.2514.

Compound 18. This compound was obtained from compound 7 employing method D. White solid. Yield $67 \% .{ }^{1} \mathrm{H}$ NMR (400 MHz, $\mathrm{CDCl}_{3}$ ) $\delta 8.39(\mathrm{~s}, 1 \mathrm{H}), 6.88(\mathrm{~s}, 1 \mathrm{H}), 6.82(\mathrm{~s}, 1 \mathrm{H})$, $3.86(\mathrm{~s}, 3 \mathrm{H}), 3.17(\mathrm{~d}, J=15.6 \mathrm{~Hz}, 1 \mathrm{H}), 2.93-2.81(\mathrm{~m}, 2 \mathrm{H}), 2.76$ (d, $J=15.8 \mathrm{~Hz}, 1 \mathrm{H}), 2.70(\mathrm{~s}, 3 \mathrm{H}), 2.60(\mathrm{qd}, J=7.4,2.4 \mathrm{~Hz}, 2 \mathrm{H}), 1.97$ $(\mathrm{dd}, J=12.7,5.8 \mathrm{~Hz}, 1 \mathrm{H}), 1.87(\mathrm{~d}, J=12.3 \mathrm{~Hz}, 1 \mathrm{H}), 1.81-1.73(\mathrm{~m}$, 1H), 1.37 (s, 3H), $1.34(\mathrm{~s}, 3 \mathrm{H}), 1.20(\mathrm{t}, J=7.5 \mathrm{~Hz}, 3 \mathrm{H}), 1.16$ (s, $3 \mathrm{H}) .{ }^{13} \mathrm{C} \mathrm{NMR}\left(100 \mathrm{MHz}, \mathrm{CDCl}_{3}\right) \delta 172.38,165.89,157.61$, 155.92, 143.94, 130.78, 129.35, 127.23, 123.88, 107.18, 55.51, 49.52, 40.97, 39.66, 36.96, 31.27, 30.41, 25.86, 24.11, 23.15, 22.73, 20.69, 14.07. HRMS (ESI): calcd for $\mathrm{C}_{23} \mathrm{H}_{31} \mathrm{~N}_{2} \mathrm{O}[\mathrm{M}+\mathrm{H}]^{+}$, 351.2431; found, 351.2417.

Compound 19. This compound was obtained from compound 7 employing method B. White solid. Yield $93 \% .{ }^{1} \mathrm{H}$ NMR $\left(400 \mathrm{MHz}, \mathrm{CDCl}_{3}\right) \delta 8.38(\mathrm{~s}, 1 \mathrm{H}), 7.05(\mathrm{~d}, J=5.2 \mathrm{~Hz}, 1 \mathrm{H})$, $6.85(\mathrm{~s}, 1 \mathrm{H}), 5.08-5.02(\mathrm{~m}, 1 \mathrm{H}), 3.90$ (s, 3H), 3.16 (d, $J=15.5 \mathrm{~Hz}$, 
$1 \mathrm{H}), 2.95-2.78(\mathrm{~m}, 3 \mathrm{H}), 2.70(\mathrm{~s}, 3 \mathrm{H}), 1.98(\mathrm{dd}, J=12.6,5.6 \mathrm{~Hz}$, $1 \mathrm{H}), 1.88-1.70(\mathrm{~m}, 3 \mathrm{H}), 1.51$ (dd, $J=6.5,2.8 \mathrm{~Hz}, 3 \mathrm{H}), 1.37$ (s, $3 \mathrm{H}), 1.34(\mathrm{~s}, 3 \mathrm{H}), 1.15(\mathrm{~s}, 3 \mathrm{H}) .{ }^{13} \mathrm{C} \mathrm{NMR}\left(100 \mathrm{MHz}, \mathrm{CDCl}_{3}\right)$ $\delta 172.34,165.98,157.59,155.16,145.60,131.58,127.70,126.80$, 123.69, 107.50, 66.42, 55.42, 49.47, 40.94, 39.68, 37.08, 31.27, $30.48,25.82,24.09,23.15,22.81,20.61$. HRMS (ESI): calcd for $\mathrm{C}_{23} \mathrm{H}_{31} \mathrm{~N}_{2} \mathrm{O}_{2}[\mathrm{M}+\mathrm{H}]^{+}$, 367.2380; found, 367.2382.

Compound 20. This compound was obtained from compound 19 employing method E. White solid. Yield $80 \% .{ }^{1} \mathrm{H}$ NMR $\left(400 \mathrm{MHz}, \mathrm{CDCl}_{3}\right) \delta 8.39(\mathrm{~s}, 1 \mathrm{H}), 7.20$ (s, 1H), 6.99 (dd, $J=$ 17.8, 11.2 Hz, 1H), 6.85 (s, 1H), 5.72 (dd, $J=17.7,1.6 \mathrm{~Hz}, 1 \mathrm{H})$, $5.24(\mathrm{dd}, J=11.1,1.6 \mathrm{~Hz}, 1 \mathrm{H}), 3.88$ (s, 3H), 3.17 (d, $J=15.5 \mathrm{~Hz}$, $1 \mathrm{H}), 2.98-2.92(\mathrm{~m}, 1 \mathrm{H}), 2.87-2.74(\mathrm{~m}, 2 \mathrm{H}), 2.70(\mathrm{~s}, 3 \mathrm{H}), 1.98(\mathrm{dd}$, $J=12.6,5.7 \mathrm{~Hz}, 1 \mathrm{H}), 1.87(\mathrm{~d}, J=13.3 \mathrm{~Hz}, 1 \mathrm{H}), 1.81-1.74(\mathrm{~m}, 1 \mathrm{H})$, 1.37 (s, 3H), 1.35 (s, 3H), 1.16 (s, 3H). ${ }^{13} \mathrm{C} \mathrm{NMR}\left(100 \mathrm{MHz}, \mathrm{CDCl}_{3}\right)$ $\delta 172.29,165.96,157.61,155.33,146.45,131.29,127.62,127.03$, 125.08, 123.69, 114.26, 107.97, 55.75, 49.43, 40.89, 39.69, 37.18, 31.27, 30.42, 25.85, 24.06, 23.17, 20.63. HRMS (ESI): calcd for $\mathrm{C}_{23} \mathrm{H}_{29} \mathrm{~N}_{2} \mathrm{O}[\mathrm{M}+\mathrm{H}]^{+}$, 349.2274; found, 349.2270.

Compound 21. This compound was obtained from compound 7 employing method C. White solid. Yield $70 \% .{ }^{1} \mathrm{H}$ NMR $\left(400 \mathrm{MHz}, \mathrm{CDCl}_{3}\right) \delta 8.45(\mathrm{~s}, 1 \mathrm{H}), 8.44(\mathrm{~s}, 1 \mathrm{H}), 7.01(\mathrm{~s}, 1 \mathrm{H})$, 4.05 (s, 3H), 3.30 (d, $J=15.5 \mathrm{~Hz}, 1 \mathrm{H}), 2.91$ (d, $J=15.4 \mathrm{~Hz}, 1 \mathrm{H})$, 2.81-2.75 (m, 2H), $2.71(\mathrm{~s}, 3 \mathrm{H}), 2.61(\mathrm{~s}, 3 \mathrm{H}), 2.43(\mathrm{dd}, J=13.5$, $4.1 \mathrm{~Hz}, 1 \mathrm{H}), 1.39(\mathrm{~s}, 3 \mathrm{H}), 1.38(\mathrm{~s}, 3 \mathrm{H}), 1.29$ (s, 3H). ${ }^{13} \mathrm{C}$ NMR $(100$ $\left.\mathrm{MHz}, \mathrm{CDCl}_{3}\right) \delta 198.40,195.80,170.80,166.61,162.65,157.85$, $157.70,130.59,127.76,124.13,122.08,107.23,55.99,47.33$, 39.64, 39.43, 37.73, 36.46, 31.37, 30.72, 25.84, 23.70, 22.04. HRMS (ESI): calcd for $\mathrm{C}_{23} \mathrm{H}_{27} \mathrm{~N}_{2} \mathrm{O}_{3}[\mathrm{M}+\mathrm{H}]^{+}, 379.2016$; found, 379.2009 .

\section{Testosterone assays}

TM3 cells were seeded in 24-well plates at a density of $1.0 \times 10^{5}$ cells per well and incubated overnight. The culture medium was then replaced with fresh medium containing various compounds $(20 \mu \mathrm{M})$ respectively. After incubation for $24 \mathrm{~h}$, the culture medium was collected and centrifuged at $1000 \times g$ for $5 \mathrm{~min}$. Testosterone concentrations in the supernatant were determined with enzyme-linked immunosorbent assay (EISA) kits (Shanghai XinFan Biological Technology Co Ltd, Shanghai, China).

\section{Cell lines and culture conditions}

The cell lines used in this study were obtained from the American Type Culture Collection (ATCC). NCM460, L-02 and PTN1A cell lines were cultured in RPMI 1640 medium containing 10\% foetal bovine serum (FBS), and TM3 mouse Leydig cell line was cultured in Dulbecco's modified eagle's medium (DMEM)/F12 medium, which was supplemented with $2.5 \%$ FBS and 5\% horse serum. Moreover, HAF cell line was cultured in DMEM medium with $1 \%$ glutamine and $10 \%$ FBS. All cells were incubated at $37{ }^{\circ} \mathrm{C}$ and $5 \% \mathrm{CO}_{2}$ incubator.

\section{Cell viability assay}

The cell viability of cell lines in the presence of this series of compounds was determined by SRB (Sigma Aldrich) assay. In brief, cells were plated at the appropriate cell densities in 96well plates during the experiment. After incubation for $24 \mathrm{~h}$, the cells were treated with different concentrations of various compounds for $24 \mathrm{~h}$. Control group were exposed to DMSO at a concentration equivalent to that of the compound-treated cells. After treatment, $25 \mu \mathrm{L}$ of $50 \%$ TCA was added for cell fixation at $4{ }^{\circ} \mathrm{C}$. After 1 hour or more, the plates were washed by water for five times. The plates were allowed to dry using hair dryer followed by being dyed with $100 \mu \mathrm{L} 0.4 \%$ SRB for $10 \mathrm{~min}$. After dying, the plates were washed by $1 \%$ acetic acid to remove the dye and allowed to dry using hair dryer. $100 \mu \mathrm{L}$ of $10 \mathrm{mM}$ Tris-based solution was added to each well, and absorbance was measured using a 96-well plate reader at $515 \mathrm{~nm}$. Three independent experiments were carried out in triplicate. The $\mathrm{IC}_{50}$ was calculated using GraphPad Software.

\section{Western blot analysis}

Cells were exposed to various concentrations of compounds for indicated time, and total cellular protein was lysed in RIPA buffer [50 mM Tris-HCl (pH 7.4), $150 \mathrm{mM} \mathrm{NaCl,} 5 \mathrm{mM}$ EDTA, 1\% Triton $\mathrm{X}-100,1 \%$ sodium deoxycholic acid, 0.1\% SDS, $2 \mathrm{mM}$ phenylmethanesulfonyl fluoride (PMSF), $30 \mathrm{mM} \mathrm{Na} \mathrm{HPO}_{4}$, $50 \mathrm{mM} \mathrm{NaF}, 1 \mathrm{mM} \mathrm{Na} \mathrm{VO}_{4}$ ] containing protease/phosphatase inhibitors (Roche). Lysates were combined with sample loading buffer and heated at $100{ }^{\circ} \mathrm{C}$. Protein concentrations were measured by a Bicinchoninic acid assay (Thermo Scientific). Lysates were mixed with sample loading buffer and heated at $100{ }^{\circ} \mathrm{C}$. for $15 \mathrm{~min}$. After separated by $8-15 \%$ SDS-PAGE, extracted protein were transferred to nitrocellulose membranes. Membranes were incubated in $5 \%(\mathrm{w} / \mathrm{v})$ bovine serum albumin (TBST/BSA) and stored overnight at $4{ }^{\circ} \mathrm{C}$ on a shaker with specific primary antibodies (1/1000 in TBST/BSA). Then membranes were washed with TBST and incubated for 45 min with secondary antibody (1/10 000 in TBST/BSA) at room temperature. Immunoreactive proteins were visualized using the Odyssey Fluorescence Scanner (LI-COR Bioscience, Inc., Lincoln, NE, USA). The StAR (ab133657; $1: 3000)$, HSD3B1 (ab65156; $1:$ 1000) and CYP11A1 (BS6578; $1: 1000)$ antibodies were purchased from Abcam (Cambridge, MA) and Bioworld Technology, Inc (St. Paul, MN). LC3A/B (12741; $1: 3000)$ and Atg5 (12994; $1: 3000)$ antibodies were purchased from Cell Signaling Technology (Danvers, MA). The $\beta$-actin and GAPDH antibody (1 : 10 000) was purchased from Sigma (St Louis, MO). The secondary antibody was conjugated with IRDye $680 / 800$ (Millennium Science; 926-32221, 926-32210; 1 : 10 000).

\section{Quantitative real-time polymerase chain reaction (qRT-PCR)}

Total RNA was extracted from cells with TRIZOL reagent (Invitrogen, Carlsbad, CA, USA) according to the manufacturer's protocols. Total RNA ( $1 \mu \mathrm{g})$ was converted to cDNA using a PrimeScript reverse transcription Master Mix kit (TaKaRa, Japan) according to the manufacturer's instructions. Quantitative RTPCR was performed using SYBR Premix Ex Taq ${ }^{\mathrm{TM}}$ Kit (TaKaRa, Japan). The relative expression of StAR, 3 $\beta$-HSD and CYP11A1 were analyzed by RT-PCR with $\beta$-actin as an internal control. 
Three independent experiments were carried out in triplicate. The gene-specific primers are listed in Table S1. $\dagger$

\section{Statistical analysis}

Grouped data are expressed as mean \pm s.d. Significance between groups was analysed by one-way analysis of variance or Student's $t$-test using GraphPad Prism 5.0 (GraphPad Software). Data were expressed as mean and S.D., and $P<0.05$ was considered significant. All experiments were performed at least three times except for animal experiments.

\section{Conflicts of interest}

There are no conflicts of interest to declare.

\section{Abbreviations}

$\begin{array}{ll}\text { NPL } & \text { Natural product-like } \\ \text { LOH } & \text { Late-onset hypogonadism } \\ \text { StAR } & \text { Steroidogenic acute regulatory } \\ \text { 3ß-HSD } & \text { 3ß-Hydroxysteroid dehydrogenase } \\ \text { CYP11A1 } & \text { Cytochrome P450 family 11 subfamily A member 1 } \\ \text { TRT } & \text { Testosterone replacement therapy } \\ \text { ED } & \text { Erectile dysfunction } \\ \text { LH } & \text { Luteinizing hormone } \\ \text { cAMP } & \text { Cyclic adenosine monophosphate } \\ \text { PKA } & \text { Protein kinase A } \\ \text { TG } & \text { Triglyceride } \\ \text { IBX } & \text { 2-Iodoxybenzoic acid } \\ \text { THF } & \text { Tetrahydrofuran } \\ \text { SAR } & \text { Structure-activity relationship } \\ \text { Rt } & \text { Room temperature } \\ \text { ELISA } & \text { Enzyme-linked immuno sorbent assay } \\ \text { IC } & \text { Half maximal inhibitory concentration } \\ \text { SRB } & \text { Sulforhodamine B } \\ \text { RT-PCR } & \text { Real-time polymerase chain reaction } \\ \text { NMR } & \text { Nuclear magnetic resonance } \\ \text { GAPDH } & \text { Reduced glyceraldehyde-phosphate dehydrogenase } \\ \text { LC3 } & \text { Light chain 3 } \\ \text { ATG5 } & \text { Autophagy related 5 } \\ \text { H\&E } & \text { Haematoxylin and eosin } \\ \text { IHC } & \text { Immunohistochemical } \\ \text { TMS } & \text { Tetramethylsilane } \\ \text { IF } & \text { Immunofluorescence } \\ \text { PMSF } & \text { Phenylmethanesulfonyl fluoride } \\ \text { SDS- } & \text { Sodium dodecyl sulfate polyacrylamide gel } \\ \text { PAGE } & \text { electrophoresis } \\ \text { TBST } & \text { Tris buffered saline tween } \\ \text { BSA } & \text { Bovine serum albumin } \\ \text { FITC } & \text { Fluorescein isothiocyanate } \\ & \end{array}$

\section{Acknowledgements}

This work was supported by Shanghai Science and Technology Council (Grant 18ZR1411200), National Natural Science Foundation of China (No. 81773204, No. 81472788) and Major State
Basic Research Development Program of China (2015CB910400).

\section{References}

1 A. Vasas and J. Hohmann, Chem. Rev., 2014, 114, 8579-8612. 2 X. Rao, X. Huang, L. He, J. Song, Z. Song and S. Shang, Comb. Chem. High Throughput Screening, 2012, 15, 840-844.

3 N. Duarte, A. Varga, G. Cherepnev, R. Radics, J. Molnar and M. J. U. Ferreira, Bioorg. Med. Chem., 2007, 15, 546-554.

4 K. Yoshikawa, N. Kokudo, M. Tanaka, T. Nakano, H. Shibata, N. Aragaki, T. Higuchi and T. Hashimoto, Chem. Pharm. Bull., 2008, 56, 89-92.

5 Y. Tian, W. Xu, C. Zhu, S. Lin, Y. Li, L. Xiong, S. Wang, L. Wang, Y. Yang, Y. Guo, H. Sun, X. Wang and J. Shi, J. Nat. Prod., 2011, 74, 1221-1229.

6 C. Lipina and H. S. Hundal, Cell. Signalling, 2014, 26, 23432349.

7 T. T. Dao, K. Y. Lee, H. M. Jeong, P. H. Nguyen, T. L. Tran, P. T. Thuong, B. T. Nguyen and W. K. Oh, J. Nat. Prod., 2011, 74, 2526-2531.

8 M. Shahlaei, S. M. Ghanadian, A. M. Ayatollahi, M. A. Mesaik, O. M. Abdalla, S. Afsharypuor and M. Rabbani, Med. Chem. Res., 2003, 22, 1795-1803.

9 C. S. Kim, L. Subedi, S. Y. Kim, S. U. Choi, K. H. Kim and K. R. Lee, J. Nat. Prod., 2016, 79, 387-394.

10 E. J. Richmond and A. D. Rogol, Nat. Clin. Pract. Endocrinol. Metab., 2007, 3, 338-344.

11 S. G. Haider, Endocrinology, 2007, 148, 2581-2582.

12 C. Wang, E. Nieschlag, R. Swerdloff, H. M. Behre, W. J. Hellstorm, L. J. Gooren, J. M. Kaufman, J. Legros, B. Lunenfeld, A. Morales, J. E. Morley, C. Schulman, I. M. Thompson, W. Weidner and F. C. W. Wu, Eur. Urol., 2009, 55, 121-130.

13 D. Sun, Y. Cui, B. Jin, X. Zhang, X. Yang and C. Gao, Evid. Based Complement. Alternat. Med., 2012, 2012, 1-10.

14 B. Lunenfeld, F. Saad and C. E. Hoesl, Aging Male, 2005, 8, 59-74.

15 C. H. Liao, Y. N. Wu, F. Y. Lin, W. K. Tsai, S. P. Liu and H. S. Chiang, Andrology, 2013, 1, 563-569.

16 N. Bassil, S. Alkaade and J. E. Morley, Ther. Clin. Risk Manage., 2009, 5, 427-448.

17 S. Kliesch, Urologe A, 2010, 49, 32-36.

18 J. I. Makinen and I. Huhtaniemi, Gerontology, 2011, 57, 193202.

19 R. Vigen, C. I. O'Donnell, A. E. Baron, G. K. Grunwald, T. M. Maddox, S. M. Bradley, A. Barqawi, G. Woning, M. E. Wierman, M. E. Plomondon, J. S. Rumsfeld and P. M. Ho, J. Am. Med. Assoc., 2013, 310, 1829-1836.

20 M. L. Dufau, Annu. Rev. Physiol., 1988, 50, 483-508.

21 K. Henriksen, H. Hakovirta and M. Parvinen, Endocrinology, 1995, 136, 3285-3291.

22 J. D. Rabinowitz and E. White, Science, 2010, 330, 1344-1348. 23 F. Gao, G. Li, C. Liu, H. Gao, H. Wang, W. Liu, M. Chen, Y. Shang, L. Wang, J. Shi, W. Xia, J. Jiao, F. Gao, J. Li, L. Chen and W. Li, J. Cell Biol., 2018, 217, 2103-2119. 
24 G. Wei, Y. Wu, X. L. He, T. Liu, M. Liu, J. Luo and W. W. Qiu, Eur. J. Med. Chem., 2017, 131, 48-67.

25 L. G. Yu, T. F. Ni, W. Gao, Y. He, Y. Y. Wang, H. W. Cui, C. G. Yang and W. W. Qiu, Eur. J. Med. Chem., 2015, 90, 10-20.
26 A. Eschenmoser and D. Arigoni, Helv. Chim. Acta, 2005, 88, 3011-3050.

27 G. Stork and A. W. Burgstaher, J. Am. Chem. Soc., 1955, 77, 5068-5077.

28 Z. B. Zhang and Q. T. Yang, Asian J. Androl., 2006, 8, 601-605. 